Asian J. Med. Biol. Res. 2020, 6 (2), 311-315; doi: 10.3329/ajmbr.v6i2.48077

\author{
Asian Journal of \\ Medical and Biological Research \\ ISSN 2411-4472 (Print) 2412-5571 (Online) \\ www.ebupress.com/journal/ajmbr
}

\title{
Article \\ Antagonistic effect of Lactobacillus spp. on experimentally Vibrio spp. infected Penaeus monodon
}

Manash Kabiraj*, Prosenzit Kumar Das, Shamima Sultana and Ghausiatur Reza Banu

Fisheries and Marine Resource Technology Discipline, Khulna University, Khulna-9208, Bangladesh

*Corresponding author: Manash Kabiraj, Fisheries and Marine Resource Technology Discipline, Khulna

University, Khulna-9208, Bangladesh. Phone: +8801731500736; E-mail: manash.kabiraj@ gmail.com

Received: 31 May 2020/Accepted: 22 June 2020/ Published: 30 June 2020

\begin{abstract}
The research was aimed to determine the present status of probiotics (Lactobacillus spp.) and pathogenic bacteria (Vibrio spp.) of culture pond as well as to determine whether the isolated probiotic Lactobacillus spp. can act as a controlling agent on experimentally pathogenic Vibrio spp. infected Penaeus monodon. In In-vitro test of gills and intestinal tracts, the potential antagonistic activity of Lactobacillus spp. toward Vibrio spp. was gradually observed at $4^{\text {th }}$ hour of probiotic treatment. At $12^{\text {th }}$ hour the viable count of Vibrio spp. was drastically reduced in gill from $2.33 \times 10^{5}$ to $1.03 \times 10^{3}\left(\mathrm{CFUg}^{-1}\right)$ and in intestinal tract $2.35 \times 10^{5}$ to $6.43 \times 10^{2}\left(\mathrm{CFUg}^{-1}\right)$. While, in In-vivo test, in case of muscle, gills and intestinal tract antagonistic activity of Lactobacillus spp. toward Vibrio spp. was noticed after 9 hours, 21 hours and 27 hours respectably of probiotic injected shrimps. However, only the result of in-vitro challenge test revealed that, Lactobacillus spp. significantly reduced the Vibrio spp. viable count of the gills of the selected samples $(\mathrm{P}=0.037)$. The investigation showed antagonistic effect of probiotic (Lactobacillus spp.) on experimentally Vibrio spp. infected shrimp.
\end{abstract}

Keywords: Lactobacillus spp.; Vibrio spp.; shrimp; In-vitro; In-vivo

\section{Introduction}

Shrimp culture is one of the fastest-growing animal food-producing sector which play a vital role to fulfill the demand of protein and economic development. In spite of this great potentiality, this sector is facing major economic losses due to a wide range of bacterial diseases. Among various diseases, Vibriosis is a potentially serious illness caused by a group of bacteria called Vibrio in shrimp worldwide. Though, both prophylactic and therapeutic chemicals as well as antibiotics are widely used to combat these pathogens in shrimp hatcheries and culture site, antibiotic resistance has become a critical threat to aquaculture as well as to global health. However, keeping mind of the above mentioned issues, several efforts has been taken current years to develop strategies for microbial control in aquaculture sector in alternative of the application of therapeutic chemicals and antibiotics. The application of probiotics is the prominent one. The prolegomenon of probiotics to control pathogens in aquaculture is well documented and crucial for the future of environment friendly aquaculture (Noh et al., 1994; Gomezgil, 1995; Bogut et al., 1998; Nowroozi et al., 2004; Nayak, 2010; Austin and Austin, 2012).

Therefore, the present study was aimed to observe the present scenario of probiotic bacteria (Lactobacillus spp.) and pathogenic bacteria (Vibrio spp.) of culture ponds by isolating from collected shrimps as well as to perform both In-vitro and In-vivo challenge test to observe antagonistic effect of probiotics Lactobacillus spp. towards experimentally Vibrio spp. infected shrimps. 
2. Materials and Methods

\subsection{Sample collection}

Shrimp samples of average weight and length of $15 \pm 3 \mathrm{~g}$ and $12 \pm 2 \mathrm{~cm}$ respectively were collected by using random sampling technique from different culture ponds located at Dumuria upazilla of Khulna District, Bangladesh. Live samples were immediately carried to the laboratory of Fisheries Molecular Pathology, Fisheries and Marine Resource Technology (FMRT) Discipline of Khulna University by using separate oxygenated polythene bags. The shrimps were aseptically dissected and the organ samples of gill and intestinal tract were removed gently to isolate and enumeration of Lactobacillus spp. and Vibrio spp. (Hameed et al., 1998). Fifty live shrimp samples weighting from $26.80 \mathrm{~g}$ to $60.20 \mathrm{~g}(15.60 \mathrm{~cm}$ to $19.50 \mathrm{~cm})$ were collected for experimental infection and In-vivo analysis.

\subsection{Isolation and enumeration technique of Lactobacillus spp. and Vibrio spp. from collected samples}

Here, gills and intestinal tracts of the collected shrimp samples were used to as sample organs for isolating both Lactobacillus spp. and Vibrio spp. We followed the method described by Nowroozi et al. (2004) as well as Hirsch (1960) for the isolating Lactobacillus spp. and preparing stock solution from sample organs respectively. While ISO procedure (ISO/TS 21872-1, 2007) was followed to isolate Vibrio spp. from sample organs of the collected samples. Finally, the number of colonies was enumerated after incubation.

\subsection{In-vitro challenge test of the isolated probiotic towards the Vibrio spp. collected from sample}

At first to prepare stock solution of organs of each shrimp were aseptically dissected. Then organs were taken into eppendorf tube with peptone water and homogenized by tissue homogenizer. After that homogenized solutions were centrifuged at $3000 \mathrm{rpm}$ for 3 minutes. The upper liquid portion was collected with a micropipette and taken into eppendorf tube after centrifugation (Hameed et al. 1998). After that $0.5 \mathrm{ml}$ isolated probiotic solution and $0.5 \mathrm{ml}$ of test solution were mixed and kept for 4 hours for proper mixing. That duration was given for finding the antagonistic effect of lactobacillus against Vibrio spp. Then, TCBS agar media was used for inoculation of $0.1 \mathrm{ml}$ mixer solution and this procedure was repeated at intervals of 4 hours up to 12 hours. Same procedure also applied for test solution of each sample without probiotic. Finally, inoculated TCBS agar plates were subjected to incubation $\left(37^{0} \mathrm{C}, 24 \pm 3\right.$ hours). Lastly, standard plate count was conducted (BBSOP0019-ss04, 2015).

\subsection{In-vivo challenge test of the isolated probiotic on the experimental shrimps}

The day before starting the in-vivo test, 50 shrimps were collected and transferred in aquariums. Shrimps were cultured in three subsequent aquariums. Aquarium-1 (negative control) contained 18 samples. The rest of the two aquariums contained 16 shrimps. 2 shrimps were sampled from negative control aquarium to enumerate the initial Vibrio spp. load of in-vivo challenge test. Water volume, salinity, dissolve $\mathrm{O}_{2}$ and temperature were $100 \pm 3$ liters, $5 \pm 0.32 \mathrm{ppt}, 4.5 \pm 0.46 \mathrm{mg} / \mathrm{L}$ and $26 \pm 1.2^{\circ} \mathrm{C}$ respectively.

1 loop full Lactobacillus spp. was stirred with $1 \mathrm{ml}$ peptone water while 1 loop full Vibrio spp. was with $1 \mathrm{ml}$ ASPW properly in different sterilized test tubes as well as further used for administration. After that, sterilized insulin syringe was used for administration of Lactobacillus spp. and Vibrio spp. solution.

Samples of aquarium-1 were injected with alkaline saline peptone water (mock infection) and denoted as negative control. Whereas a group of shrimps (32) were artificially injected with Vibrio spp. ( $0.1 \mathrm{ml}$ solution) and kept in aquarium-2 as positive control. Half of those shrimps (16 individuals) were again injected with Lactobacillus spp. ( $0.1 \mathrm{ml}$ solution) and kept in aquarium-3 as treatment. The injection was administered at $45^{\circ}$ angels with the vertical axis of each shrimp body in the ventral portion of $2^{\text {nd }}$ abdominal segment, no anesthesia was used during injecting process. After that their muscles and intestinal tracts were collected for further experiment.

Before injection only two (02) samples were taken from $1^{\text {st }}$ aquarium (negative control) to enumerate the total Vibrio spp. load. Then samples were collected at 03, 09, 15, 21, 27, 33, 39 and 45 hours after injection.

Finally, marking and preservation of samples in deep freeze $\left(-40^{\circ} \mathrm{C}\right)$ were conducted for further laboratory analysis. Then the isolation and enumeration of Lactobacillus and Vibrio spp. load in gill and gut were accomplished. Every time, two shrimps were sacrificed from each group of experiment. For bacterial colony count, each sample was spread on three different petri dished as replication. 
2.5. Statistical analysis

The data collected during experiment were recorded. Data were analyzed using MS excel and the statistical package SPSS (16). One-way ANOVA was performed to observe the degree of difference between the treatments at the $5 \%$ level of significance.

\section{Results}

3.1. Enumeration of bacterial load of various organs of the collected samples (P. monodon)

The average Lactobacillus spp. and Vibrio spp. count in sample organs of collected shrimps are presented in Table 1.

\subsection{In-vitro challenge test}

In-vitro challenge test showed a reduction of Vibrio spp. load in gills after 4 hours of probiotic application. But a drastic reduction in the load of Vibrio spp. obtained at $12^{\text {th }}$ hour of probiotic application. Similarly, in case of intestinal tracts the load of Vibrio spp. was lowest after 12 hours of probiotic application (Table 2).

\subsection{In-vivo challenge test}

There was no presence of Vibrio spp. in the muscle of the samples taken from the negative control aquarium in each sampling interval. In in-vivo challenge test, significant reduction of Vibrio spp. load in the experimental muscle had been obtained from $21^{\text {st }}$ hour to rest of the time intervals of probiotic application (Table 3 ). Whereas, significant reduction of Vibrio spp. in intestine noticed after 27 hours of probiotic treatment.

Table 1. Total Lactobacillus spp. and Vibrio spp. count in selected organs of collected shrimp.

\begin{tabular}{|c|c|c|c|c|}
\hline \multirow[b]{2}{*}{$\begin{array}{l}\text { Pond } \\
\text { No. } \\
\end{array}$} & \multicolumn{2}{|c|}{ Gill } & \multicolumn{2}{|c|}{ Intestinal tract } \\
\hline & $\begin{array}{l}\text { Average Lactobacillus } \\
\text { load }\left(\mathrm{CFUg}^{-1}\right)\end{array}$ & $\begin{array}{l}\text { Average Vibrio spp. } \\
\text { load }\left(\mathrm{CFUg}^{-1}\right)\end{array}$ & $\begin{array}{l}\text { Average Lactobacillus } \\
\text { load }\left(\mathrm{CFUg}^{-1}\right)\end{array}$ & $\begin{array}{l}\text { Average Vibrio spp. } \\
\text { load }\left(\mathrm{CFUg}^{-1}\right)\end{array}$ \\
\hline 01 & $1.54 \times 10^{5}$ & $4.03 \times 10^{3}$ & $6.45 \times 10^{3}$ & $7.23 \times 10^{2}$ \\
\hline 02 & $4.50 \times 10^{4}$ & $2.02 \times 10^{3}$ & $2.56 \times 10^{3}$ & $4.57 \times 10^{2}$ \\
\hline 03 & $2.37 \times 10^{4}$ & $1.12 \times 10^{3}$ & $1.74 \times 10^{3}$ & $3.64 \times 10^{2}$ \\
\hline 04 & $1.49 \times 10^{5}$ & $1.35 \times 10^{4}$ & $1.81 \times 10^{4}$ & $1.04 \times 10^{3}$ \\
\hline 05 & $2.10 \times 10^{5}$ & $6.37 \times 10^{3}$ & $3.08 \times 10^{4}$ & $1.22 \times 10^{3}$ \\
\hline 06 & $3.24 \times 10^{4}$ & $2.30 \times 10^{3}$ & $2.61 \times 10^{4}$ & $1.72 \times 10^{3}$ \\
\hline
\end{tabular}

Table 2. In-vitro challenge test and enumeration of Vibrio spp. load in gills and intestinal tracts with and without probiotics.

\begin{tabular}{|c|c|c|c|c|}
\hline \multirow{2}{*}{$\begin{array}{l}\text { Interval } \\
\text { (Hours) }\end{array}$} & \multicolumn{2}{|c|}{ Gills } & \multicolumn{2}{|c|}{ Intestinal tracts } \\
\hline & $\begin{array}{l}\text { Without probiotics } \\
\text { Average Vibrio spp. } \\
\text { load }\left(\mathrm{CFUg}^{-1}\right)\end{array}$ & $\begin{array}{l}\text { With probiotics } \\
\text { Average Vibrio spp. } \\
\text { load }\left(\mathrm{CFUg}^{-1}\right)\end{array}$ & $\begin{array}{l}\text { Without probiotics } \\
\text { Average Vibrio spp. } \\
\text { load }\left(\mathrm{CFUg} \mathrm{g}^{-1}\right)\end{array}$ & $\begin{array}{l}\text { With Probiotics } \\
\text { Average Vibrio spp. } \\
\text { load }\left(\mathrm{CFUg}^{-1}\right)\end{array}$ \\
\hline 00 & $7.625 \times 10^{3}$ & 0 & $5.645 \times 10^{3}$ & 0 \\
\hline 04 & $5.5590 \times 10^{4}$ & $9.35 \times 10^{2}$ & $2.9800 \times 10^{4}$ & $1.0810 \times 10^{4}$ \\
\hline 08 & $1.23850 \times 10^{5}$ & $4.840 \times 10^{3}$ & $1.22300 \times 10^{5}$ & $2.455 \times 10^{3}$ \\
\hline 12 & $2.33000 \times 10^{5}$ & $1.030 \times 10^{3}$ & $2.35100 \times 10^{5}$ & $6.43 \times 10^{2}$ \\
\hline
\end{tabular}

$* \mathrm{P}=0.037$ in Gills and $\mathrm{P}=0.069$ in Intestinal Tracts

Table 3. In-vivo challenge test of muscle, gills and intestinal tract with probiotics and without probiotics.

\begin{tabular}{|c|c|c|c|c|c|c|}
\hline \multirow[t]{2}{*}{$\begin{array}{l}\text { Interval } \\
\text { (Hours) }\end{array}$} & \multicolumn{2}{|c|}{$\begin{array}{c}\text { Average Vibrio spp. } \\
\text { load }\left(\mathrm{CFUg}^{-1}\right) \text { in muscle }\end{array}$} & \multicolumn{2}{|c|}{$\begin{array}{l}\text { Average Vibrio spp. } \\
\text { load }\left(\mathrm{CFUg}^{-1}\right) \text { in gills }\end{array}$} & \multicolumn{2}{|c|}{$\begin{array}{c}\text { Average Vibrio spp. } \\
\text { load }\left(\mathrm{CFUg}^{-1}\right) \text { in intestinal tract }\end{array}$} \\
\hline & $\begin{array}{l}\text { Without } \\
\text { probiotics }\end{array}$ & $\begin{array}{l}\text { With } \\
\text { probiotics }\end{array}$ & $\begin{array}{l}\text { Without } \\
\text { probiotics }\end{array}$ & $\begin{array}{l}\text { With } \\
\text { probiotics }\end{array}$ & $\begin{array}{l}\text { Without } \\
\text { probiotics }\end{array}$ & $\begin{array}{l}\text { With } \\
\text { probiotics }\end{array}$ \\
\hline 00 & 0 & 0 & 0 & 0 & 00 & 00 \\
\hline 03 & $6.10 \times 10^{4}$ & $1.31 \times 10^{5}$ & 0 & 0 & 00 & 00 \\
\hline 09 & $4.53 \times 10^{6}$ & $1.59 \times 10^{6}$ & $1.75 \times 10^{3}$ & $4.49 \times 10^{3}$ & 00 & 00 \\
\hline 15 & $6.65 \times 10^{6}$ & $2.74 \times 10^{6}$ & $6.48 \times 10^{4}$ & $6.80 \times 10^{4}$ & $3.83 \times 10^{3}$ & $2.88 \times 10^{3}$ \\
\hline 21 & $3.52 \times 10^{7}$ & $3.30 \times 10^{6}$ & $1.36 \times 10^{6}$ & $3.68 \times 10^{5}$ & $8.36 \times 10^{3}$ & $6.72 \times 10^{3}$ \\
\hline
\end{tabular}




\begin{tabular}{lllllll}
27 & $5.82 \times 10^{7}$ & $4.83 \times 10^{6}$ & $2.90 \times 10^{6}$ & $1.09 \times 10^{5}$ & $7.04 \times 10^{4}$ & $7.90 \times 10^{3}$ \\
33 & $7.00 \times 10^{7}$ & $7.05 \times 10^{6}$ & $3.71 \times 10^{6}$ & $2.26 \times 10^{5}$ & $1.08 \times 10^{5}$ & $8.38 \times 10^{3}$ \\
39 & $5.38 \times 10^{8}$ & $3.13 \times 10^{6}$ & $5.93 \times 10^{7}$ & $4.01 \times 10^{5}$ & $3.12 \times 10^{5}$ & $6.85 \times 10^{4}$ \\
45 & $5.73 \times 10^{9}$ & $3.42 \times 10^{7}$ & $4.30 \times 10^{7}$ & $1.02 \times 10^{5}$ & $1.98 \times 10^{5}$ & $2.06 \times 10^{4}$ \\
\hline
\end{tabular}

$* \mathrm{P}=0.469$ in Muscle; $\mathrm{P}=0.510$ in Gills and $\mathrm{P}=0.687$ in Intestinal Tract;

\section{Discussion}

The results of the present experiment revealed that both bacterial count (Vibrio spp. and Lactobacillus spp.) were much more in gills than that of intestinal tract in shrimp samples. That's because gills are external organ and play a vital role in respiration. Hence, opportunistic pathogens from the environment could taken up restlessly by different processes like respiration, osmoregulation as well as by feeding. On the contrary, intestinal tract is an internal organ and might not provide suitable and permanent adherence to the Lactobacillus spp. due to presence of different types of enzyme, digestive juice and acids. Moreover, it is well established findings that, Lactobacillus spp. are less prominent in piscine intestinal microbiome. Few strains of Lactobacillus spp. are more sensitive to incubation period and nutrient medium due to their slow growth rate, hence they need special nutrients enrich habitat. Therefore, the probability of high microbial abundance is to a greater extent on the external organs of an aquatic animal than in internal organ, which is supported by findings of different researchers (Moriarty, 1990; Ringo and Gatesoup, 1998; Hansen and Olafsen, 1999).

As we know that only effectual probiotic strains could able to colonize in intestinal mucosa through rendering the attachment site of pathogenic microbial strain by adhesion properties and could propagate chemical substances, metabolites and enzymes which are ultimately toxic or restrictive to pathogenic microbial strain; could execute immunostimulatory activity.

In-vitro testing result of the present study also unveiled a remarkable finding that, inoculated Lactobacillus spp. successfully reduced the Vibrio spp. viable count of the gills and intestinal tract of the selected samples in which marked reduction observed at 8th and 12th hour. This finding was also supported by Koga et al. (1998), Farzanfar (2006), Ramesh and Umamaheswari (2011) and Ariole and Nyeche (2013).

Whereas In-vivo diagnostic test consequence of the present study showed that, Lactobacillus spp. successfully impede the Vibrio spp. load of the muscle, gills and intestinal tract in probiotic injected shrimps gradually after 9,21 and 27 hours of probiotic injection respectively. The load of Vibrio spp. in muscle and gills was found more in Vibrio-probiotic injected shrimps than only Vibrio injected shrimps respectably at 3 and 9 hours of post inoculation. Direct administration of Vibrio spp. in muscle and stress might be responsible for this situation. As far we know not only every individual has its own defense mechanism but also every bacterium has its own latent period, could able to colonize in the gastrointestinal tract when it could persist in that environment for a long time by possessing a multiplication rate that is higher than its expulsion rate. Lactobacillus need more time to activate and multiply than Vibrio spp. (Brock and Madigan, 1991; Ringo and Gatesoupe, 1998). In-vivo is related with live organisms and many physiological factors are involved in this. This might be a reason which reduces the rate of multiplication of Lactobacillus spp. than Vibrio spp. However, a few in vivo experiment were conducted on the antagonistic activity of Lactobacillus on Vibrio spp. in crustacean (Kesarcodi-Watson et al., 2008), though this finding was supported by Griffith (1995).

\section{Conclusions}

The present investigation showed an excellent antagonistic effect of Lactobacillus spp. on experimentally Vibrio spp. infected shrimp. Therefore, Lactobacillus spp. could be used as an effective agent to control the shrimp diseases caused by pathogenic Vibrio spp. in culture system.

\section{Acknowledgments}

This research was fully supported by University Grant Commission of Bangladesh.

\section{Conflict of interest}

None to declare.

\section{References}

Ariole CN and GE Nyeche, 2013. In vitro antimicrobial activity of Lactobacillus isolates against shrimp (Penaeus monodon) pathogens. Int. J. Biosci., 3: 7-12.

Austin B and DA Austin, 2012. Bacterial fish pathogens: disease of farmed and wild animals. 5th edn Springer Dordrecht. 
BBSOP0019-04, 2015. Standard operating policy/procedure of standard bacterial plate count. United States Department of Agriculture Center for Veterinary Biologics, February 272015.

Bogut I, Z Milakovic and Z Bukvic, 1998. Influence of probiotic (Streptococcus faecium M74) on growth and content of intestinal microflora in carp (Cyprinus carpio). J. Anim. Sci., 43: 231-235.

Brock TD and MT Madigan, 1991. Biology of Microorganisms 6th edition Prentice-Hall Englewood Cliffs NJ $874 \mathrm{pp}$.

Farzanfar A, 2006. The use of probiotics in shrimp aquaculture. FEMS Immunol. Med. Microbiol., 48: 149158.

Gomezgil R, 1995. The use of bacteria as probiotics in shrimp larviculture. Larvi 95 Fish and shellfish larviculture symposium, Belgium, pp. 479-480.

Griffith DRW, 1995. Microbiology and role of the probiotics in Eucadorian shrimp hatcheries. Larvi95 Fish and shellfish larviculture symposium, Belgium, pp. 478-481.

Hameed AS, SM Anilkumar and MLS Raj, 1998. Studies on the pathogenicity of systemic ectodermal and mesodermal baculovirus and its detection in shrimp by immunological methods. Aquaculture, 160: 31-45.

Hansen GH and JA Olafsen, 1999. Bacterial interactions in early life stages of marine cold water fish. Microb. Ecol., 38: 1-26.

Hirsch JG, 1960. Comparative bactericidal activity of blood serum and plasma serum. J. Biol. 66: 391-398.

ISO/TS 21872-1, 2007. Microbiology of food and animal feeding stuffs-Horizontal method for the detection of potentially enteropathogenic Vibrio spp-Part 1: Detection of Vibrio parahaemolyticus and Vibrio cholerae Reference number: ISO/TS 21872-1:2007(E)

Kesarcodi-Watson A, H Kaspar and MJ Lategan, 2008. Probiotics in aquaculture: the need principles and mechanisms of action and screening processes. Aquaculture, 274: 1-14.

Koga T, T Mizobe and K Takumi, 1998. Antibacterial activity of Lactobacillus species against Vibrio species. Microbiol. Res., 153: 271-275.

Moriarty DJW, 1990. Interactions of microorganisms and aquatic animals particularly the nutritional role of the gut flora In: Microbiology in poecilotherms (eds R Lesel) The Netherlands: Elsevier Science; pp. 217-222.

Nayak SK, 2010. Probiotics and immunity: a fish perspective. Fish Shellfish Immun., 29: 14.

Noh SH, K Han, TH Won and YJ Choi, 1994. Effect of antibiotics enzyme yeast culture and probiotics on growth performance of Israeli carp. Korean J. Food Sci. An., 36: 480-486.

Nowroozi J, M Mirazaii and M Norouzi, 2004. Study of Lactobacillus as probiotic bacteria. Iran J. Public Health, 33: 1-7.

Ramesh K and S Umamaheswari, 2011. Inhibitory activity of antibiotics and anti-vibrio probiotics against Vibrio harveyi isolated from penaeid shrimp hatcheries. Asian Fish Sci., 24: 186-196.

Ring $\varnothing$ E and FJ Gatesoup, 1998. Lactic acid bacteria in fish: a review. Aquaculture, 160: 177-203. 